Original article

DOI: $10.2478 / 10004-1254-65-2014-2547$

\title{
In vivo changes in carbonic anhydrase activity and histopathology of gill and liver tissues after acute exposure to chlorpyrifos in rainbow trout
}

\author{
Ahmet Topal ${ }^{1}$, Muhammed Atamanalp ${ }^{2}$, Ertan Oruç3 ${ }^{3}$ Yeliz Demir ${ }^{4}$, Şükrü Beydemir ${ }^{4}$, and \\ Alparslan Işı $\mathrm{k}^{1}$
}

Department of Basic Sciences ${ }^{1}$, Department of Aquaculture ${ }^{2}$, Faculty of Fisheries, Department of Pathology, Faculty of Veterinary ${ }^{3}$, Department of Chemistry, Faculty of Science ${ }^{4}$, Ataturk University, Erzurum, Turkey

Received in June 2014

CrossChecked in June 2014

Accepted in November 2014

\begin{abstract}
Chlorpyrifos is an organophosphate pesticide widely used in agriculture and aquaculture. This study investigated its effects on carbonic anhydrase (CA) enzyme activity and histopathology of rainbow trout gill and liver. The fish were exposed to $2.25\left(25 \%\right.$ of $\left.96 \mathrm{~h} \mathrm{LC}_{50}\right), 4.5\left(50 \%\right.$ of $\left.96 \mathrm{~h} \mathrm{LC}_{50}\right)$, and $6.75 \mu \mathrm{g} \mathrm{L}^{-1}$ $\left(75 \%\right.$ of $96 \mathrm{~h} \mathrm{LC}_{50}$ ) of chlorpyrifos for $24,48,72$, and $96 \mathrm{~h}$. CA activity was measured in liver and gills and histopathological changes were examined by light microscopy. The most common liver changes at most of the chlorpyrifos concentrations were hyperaemia and degenerative changes. Gill tissues were characterised by lamellar hyperaemia, lamellar oedemas, clumping, cellular degeneration, hyperplasia, and lamellar atrophy. CA enzyme activity in the gills decreased at all concentrations at 48, 72, and $96 \mathrm{~h}$ after exposure to chlorpyrifos $(p<0.05)$. Similarly, there was a time-dependent decrease in CA activity at all of the concentrations in liver tissues $(p<0.05)$. The present study indicated that chlorpyrifos inhibits CA enzyme activity and causes histopathological damage in gill and liver tissues.
\end{abstract}

KEY WORDS: acute toxicity; fish; histology; light microscopy; organophosphate pesticides

Chlorpyrifos is an organophosphate pesticide widely used in agriculture, aquaculture, and fishery pest control $(1,2)$. Numerous environmental issues have arisen so far due to the excessive use of this chemical compound (3), as it, among other consequences, causes toxic effects in non-target aquatic organisms, especially fish (4). Fish are used to assess the health of aquatic environments and physiological changes occurring as a result of pollution and multiple studies have already established that chlorpyrifos has various detrimental effects on them (5-10), such as neurotoxicity via acetylcholinesterase inhibition (11), biochemical and histopathological alterations $(12,13)$, oxidative stress $(12,14)$, genotoxicity $(15)$, and olfactory and neurobehavioral injuries (16). It therefore poses a serious threat to aquatic organisms as well as to human health (17). Rainbow trout has been selected for this study, because it is a sensitive indicator of aquatic pollution (18) and one of the most studied fish species due to its importance as food in terms of nutritional and economic value (19).

Carbonic anhydrase (CA) is a zinc metalloenzyme found in the tissues of most eukaryotes and has important physiological functions such as respiration, gas balance, lipogenesis, ureagenesis, bone resorption, or body fluid generation in various tissues $(20,21)$. CA plays an important role in the excretion of metabolic carbon dioxide in fish and catalyses the reversible hydration/dehydration of carbon dioxide to bicarbonate and protons $(22,23)$. Therefore, any inhibition of this enzyme leads to unfavourable effects for living organisms. Additionally, CA can also be used as a biomarker of toxicity (24). 
Histological techniques are used to assess the toxic effect of pollutants such as pesticides and heavy metals in the aquatic environment (25). Little information is available on chlorpyrifos toxicity and effects on CA sensitivity in fish. This study was designed to determine CA activity levels and histopathological changes in gill and liver tissues of rainbow trout after acute exposure to chlorpyrifos.

\section{MATERIALS AND METHODS}

Our experiments were performed on rainbow trout, Oncorhynchus mykiss (body mass $171 \pm 5.73 \mathrm{~g}$ and average length $19.47 \pm 0.94 \mathrm{~cm}$ ). They were obtained from the Ataturk University Faculty of Fisheries and Inland Water Fish Breeding and Research Center. Experiments were carried out in 4 fiberglass tanks (each $400 \mathrm{~L}$ ) each containing 15 fish. The tanks were filled with dechlorinated tap water (temperature 10$12{ }^{\circ} \mathrm{C}, \mathrm{pH} 7.1 \pm 0.3$, dissolved oxygen $8.2 \pm 0.5 \mathrm{mg} \mathrm{L}^{-1}$, water hardness $174.6 \pm 5.19 \mathrm{mg} \mathrm{L}^{-1} \mathrm{CaCO}_{3}, \mathrm{SO}_{4}$ ${ }^{2}=0.36 \mathrm{mg} \mathrm{L}^{-1}, \mathrm{PO}_{4}^{-3}=$ trace, $\mathrm{NO}_{3}=1.51 \mathrm{mg} \mathrm{L}^{-1}$ and $\mathrm{NO}_{2}=$ =trace) and acclimated to laboratory conditions for 15 days. During acclimation, the fish were fed $2.5 \%$ body weight with commercial trout pellets (Sibal Group, Sinop, Turkey).

Chlorpyrifos was at $99.2 \%$ purity and the study used its commercial formulation [ $480 \mathrm{~g} \mathrm{~L}^{-1}$ chlorpyrifos, $\mathrm{O}, \mathrm{O}$-diethyl-O-(3,5,6-trichlor-2-pyridyl) phosphorothioate] purchased from a distributor company (Platin Chemistry, Turkey). The stock solution of chlorpyrifos was prepared by dissolving in distilled water.

\section{Exposure to chlorpyrifos}

The chlorpyrifos $\mathrm{LC}_{50}$ value for rainbow trout was set at $9 \mu \mathrm{g} \mathrm{L}^{-1}(26)$. The concentrations used for this study were $25 \%\left(2.25 \mu \mathrm{g} \mathrm{L}^{-1}\right), 50 \%\left(4.5 \mu \mathrm{g} \mathrm{L}^{-1}\right)$, and $75 \%\left(6.75 \mu \mathrm{g} \mathrm{L}^{-1}\right)$ of the $\mathrm{LC}_{50}$ value. These concentrations were chosen because they were lower than the lethal concentrations for rainbow trout, and also may occur in a polluted environment. The fish were exposed to these concentrations for 24, 48, 72, and $96 \mathrm{~h}$. At the end of each exposure period, fish were randomly selected from the control and exposed groups and sampled. The fish were sacrificed by cervical section and the liver and gill tissues were immediately removed. A portion of the tissues was washed with physiological saline $(0.9 \% \mathrm{NaCl})$ and stored at $-20{ }^{\circ} \mathrm{C}$ until analysis for CA activity. The other portion of the tissues was fixed in $10 \%$ formalin solution for histopathological examination.

\section{Determination of CA activity}

Liver and gill tissue samples were washed three times with $0.9 \% \mathrm{NaCl}$. Each tissue was homogenised with buffer $25 \mathrm{mmol} \mathrm{L}^{-1}$ Tris- $\mathrm{HCl}+0.1 \mathrm{~mol} \mathrm{~L}^{-1} \mathrm{Na}_{2} \mathrm{SO}_{4}$ $(\mathrm{pH} 8.7)$ by homogenizer and the supernatant was centrifuged at $4{ }^{\circ} \mathrm{C}, 15000 \mathrm{~g}$ for $60 \mathrm{~min}$. Enzyme activity was assayed by following $\mathrm{CO}_{2}$ hydration according to the protocol established by Wilbur and Anderson (27). $\mathrm{CO}_{2}$-hydratase activity as an enzyme unit (EU) was calculated by using the equation $\left(t_{0}-t_{c} /\right.$ $t_{c}$ ) where $t_{0}$ and $t_{c}$ are the times for $\mathrm{pH}$ change of the non-enzymatic and the enzymatic reactions, respectively.

\section{Histopathology procedures}

After the routine histopathology process, paraffin sections were stained in $5 \mu$ with hematoxylin and eosine (HE). Histopathological changes were semiquantitatively assessed under a light microscope (Olympus BX51 with DP72 camera attachment system, Tokyo, Japan). The scores were derived as semi-quantitative according to severity and extent of changes and are reported as follows: none:-; mild:+; moderate:++; and severe:+++.

\section{Statistical analyses}

All data are expressed as mean \pm SEM. Statistical analysis of data was done using one-way analysis of variance (ANOVA) and LSD test and analysed using SPSS version 10.0. A value of $p<0.05$ was considered statistically significant.

\section{RESULTS AND DISCUSSION}

Aquatic ecosystems are often faced with problems caused by contaminants released into the environment (28). Various non-target organisms, especially fish, are exposed to pesticides such as chlorpyrifos and this may cause many adverse effects, including biochemical alterations (29). In order to add to risk assessment studies conducted thus far, we strived to obtain information about the effects of chlorpyrifos on rainbow trout, one of the most studied species owing to its previously mentioned importance. 


\section{CA activity in liver and gill tissues}

A time-dependent decrease in enzyme activity was evident, as CA activity decreased at all of the applied concentrations in all liver and gill tissues after $96 \mathrm{~h}$ $(p<0.05)$. Exposure to 4.5 and $6.75 \mu \mathrm{g} \mathrm{L}^{-1}$ of chlorpyrifos for $72 \mathrm{~h}$ also caused a statistically significant decrease in liver and gill CA activity $(p<0.05)$. Furthermore, the $6.75 \mu \mathrm{g} \mathrm{L}^{-1}$ concentration decreased CA activity after $48 \mathrm{~h}$ in both tissues and only in gill tissues after $24 \mathrm{~h}$, while the $4.5 \mu \mathrm{g} \mathrm{L}^{-1}$ concentration also affected only gill tissue after $24 \mathrm{~h}$ when compared to the controls $(p<0.05)$ (Figures 1 and 2). There was no statistically significant difference at either of the concentrations after $24 \mathrm{~h}$ in liver tissues when compared to the control (Figure 1).
Many chemical substances lead to changes in metabolism by changing enzyme activity, particularly via inhibition of a specific enzyme (30). There are many studies in the literature about the effects of pesticides on CA activity in different fish species and rainbow trout in particular $(9,23,31,32)$. For example, the pesticides deltamethrin, diazinon, propoxur, and cypermethrin were tested on rainbow trout gill CA activity by Ceyhun et al. (33) exhibiting inhibitory effects in vivo and in vitro. In another study, Dogan (23) reported that pesticides such as lambdacyhalothrin, deltametrin, diozinon, dorzolamide, and brinzolamide caused inhibitory effects on CA activity in rainbow trout blood. CA is known to play an important role in the excretion of metabolic $\mathrm{CO}_{2}$ as

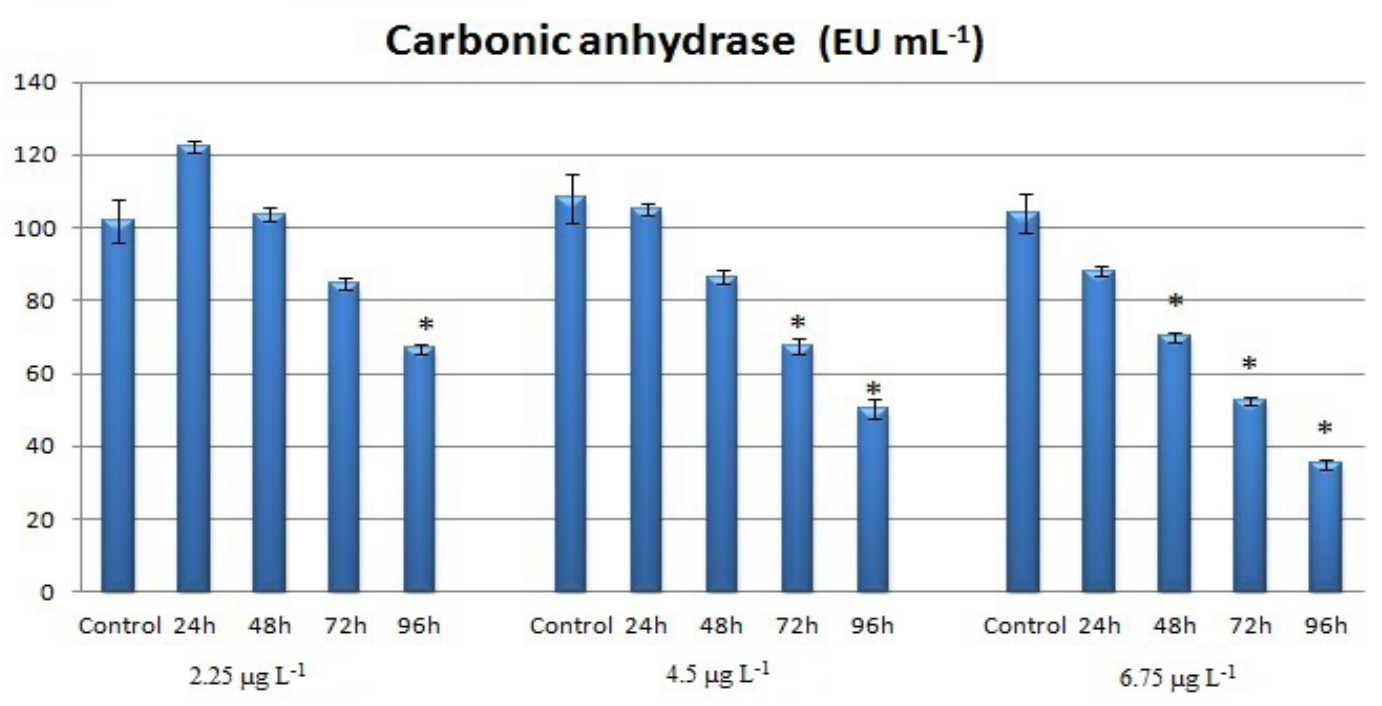

Figure 1 The effects of chlorpyrifos on liver carbonic anhydrase enzyme activity of rainbow trout. Values are expressed as mean \pm S.E.M. Significant difference from control values ${ }^{*} \mathrm{p}<0.05$. EU-enzyme units

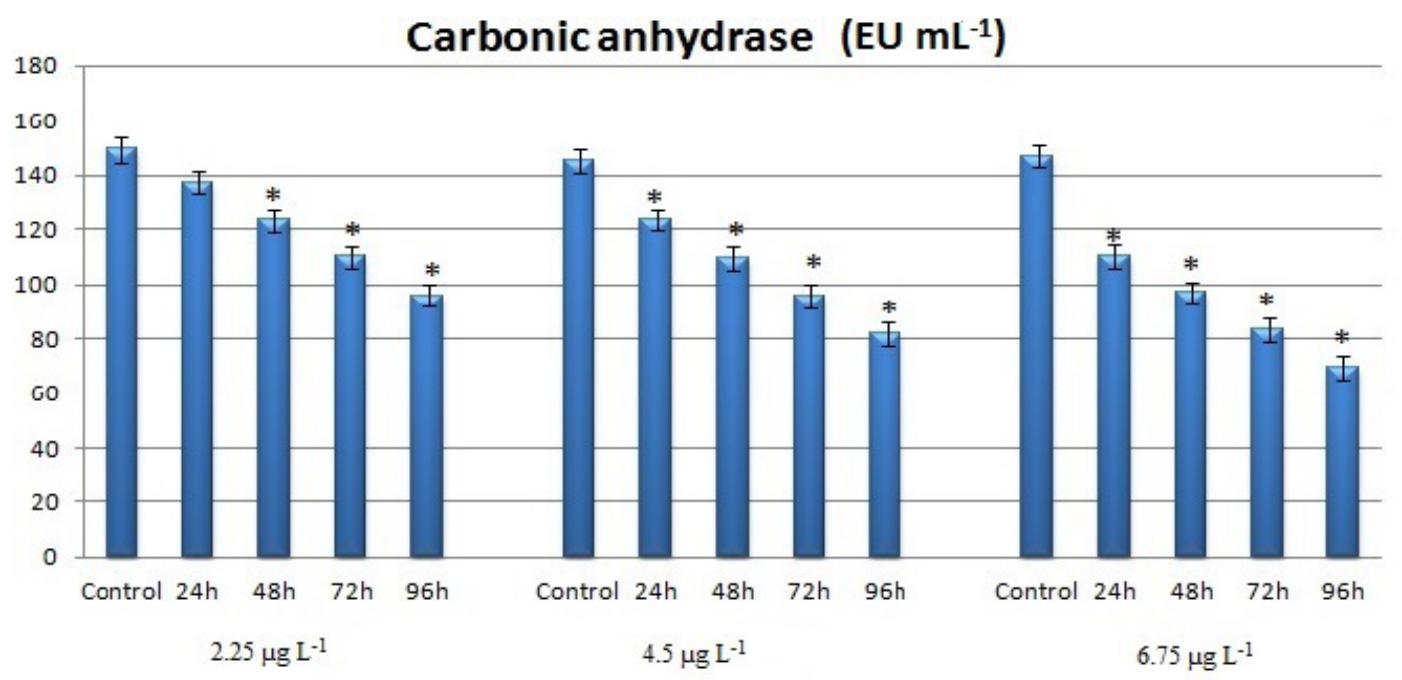

Figure 2 The effects of chlorpyrifos on gill carbonic anhydrase enzyme activity of rainbow trout. Values are expressed as mean \pm S.E.M. Significant difference from control values ${ }^{*} \mathrm{p}<0.05$. EU-enzyme units 
well as in $\mathrm{CO}_{2}$ exchange between tissues and blood in fish and in catalysing the reversible hydration/ dehydration of $\mathrm{CO}_{2}$ to bicarbonate and protons (22, 23, 34).

Our results have shown that there was a timedependent decrease in enzyme activity after exposure to chlorpyrifos at certain concentrations. This decrease can be explained by a decrease in $\mathrm{CO}_{2}$ hydration. It has been reported that, in catalysis, $\mathrm{CO}_{2}$ hydration is defined by the attack of a $\mathrm{Zn}^{2+}$ bound hydroxide on $\mathrm{CO}_{2}$ to yield a $\mathrm{Zn}^{2+}$ bound $\mathrm{HCO}_{3}^{-}$species. $\mathrm{HCO}_{3}^{-}$is subsequently replaced by water to yield a $\mathrm{Zn}^{2+}$-bound water molecule (23). In our case, the supply of $\mathrm{HCO}_{3}^{-}$ decreased with $\mathrm{H}^{+}$excretion (35). Accordingly, we can say that chlorpyrifos inhibited the enzyme at very low concentrations due to the electronegative atoms in the pesticide's chemical structures (9).

\section{Gill and liver histopathology}

In the present study, no histopathological changes were established in the control liver tissues and at $2.25 \mu \mathrm{g} \mathrm{L}^{-1}$ of chlorpyrifos (Figure 3). Hyperaemia and degenerative changes were observed at 48, 72, and $96 \mathrm{~h}$ of exposure to 4.5 and $6.75 \mu \mathrm{g} \mathrm{L}^{-1}$ of chlorpyrifos (Figure 4) (Table 1).

Fish liver histopathology is an indicator of chemical toxicity and a useful way to study the effects of the exposure of aquatic animals to toxins present in the aquatic environment (36). The effects of different pesticides on liver in various fish species have already been reported in other studies. Chlorpyrifos caused damages such as melanomacrophage aggregations, cellular atrophy, pyknotic nucleus, cytoplasmic vacuolation, cytoplasmic and nuclear degeneration, cellular rupture, necrosis, and nuclear and cellular hypertrophy in the liver tissues of the common carp, while phosalone induced histopathological changes such as nuclear degeneration, cytoplasmic vacuolation, hypertrophy, and congestion $(37,38)$.

No histopathological changes were observed in the gill tissues of the control group (Figure 3). Gill tissues showed lamellar hyperaemia at 48, 72, and $96 \mathrm{~h}$ of exposure to $2.25 \mu \mathrm{g} \mathrm{L}^{-1}$ and at 24, 48, 72, and $96 \mathrm{~h}$ at the two other concentrations (Table 1). Lamellar oedemas were intensive in all of the groups (Figures 5, 6, and 7). Apart from these, there were also other histopathological changes such as lamellar atrophy, hyperplasia, cellular degeneration, and clumping to a varying degree (Table 1).

Environmental pollutants cause pathological changes in fish physiology (39). Gills are especially suitable for histopathological examination to determine the effects of pollution because these tissues are frequently those that are adversely affected by contaminants in the aquatic environment; for instance through osmoregulatory function and reduced oxygen consumption (40-43). In support of our observation, Pal et al. (37) observed numerous lesions in the gill tissues of common carp exposed to chlorpyrifos. Ba-

Table 1 Histopathological comparison of control and experimental groups none:-, mild: + , moderate: ++ and severe: +++

\begin{tabular}{|c|c|c|c|c|c|c|c|c|c|c|c|c|c|c|c|c|}
\hline \multirow{3}{*}{ Lesion } & \multicolumn{4}{|c|}{ Control } & \multicolumn{4}{|c|}{$2.25 \mu \mathrm{g} \mathrm{L}^{-1}$} & \multicolumn{4}{|c|}{$4.5 \mu \mathrm{g} \mathrm{L}^{-1}$} & \multicolumn{4}{|c|}{$6.75 \mu \mathrm{g} \mathrm{L}^{-1}$} \\
\hline & \multicolumn{16}{|c|}{ Hours } \\
\hline & 24 & 48 & 72 & 96 & 24 & 48 & 72 & 96 & 24 & 48 & 72 & 96 & 24 & 48 & 72 & 96 \\
\hline & \multicolumn{16}{|c|}{ Liver tissue } \\
\hline Hyperaemia & - & - & - & - & - & - & - & - & - & + & + & ++ & - & + & ++ & +++ \\
\hline \multirow[t]{2}{*}{$\begin{array}{l}\text { Degenerative } \\
\text { changes }\end{array}$} & - & - & - & - & - & - & - & - & - & + & + & + & - & + & + & + \\
\hline & \multicolumn{16}{|c|}{ Gill tissue } \\
\hline $\begin{array}{l}\text { Lamellar } \\
\text { hyperaemia }\end{array}$ & - & - & - & - & - & + & + & + & + & + & + & + & + & + & + & + \\
\hline Lamellar oedema & - & - & - & - & ++ & ++ & ++ & ++ & ++ & ++ & ++ & ++ & ++ & ++ & ++ & ++ \\
\hline Clumping & - & - & - & - & + & + & + & + & + & + & + & + & + & + & + & + \\
\hline $\begin{array}{l}\text { Cellular } \\
\text { degeneration }\end{array}$ & - & - & - & - & - & - & + & + & - & + & + & + & - & + & + & + \\
\hline Hyperplasia & - & - & - & - & - & + & + & + & - & + & + & + & - & + & + & + \\
\hline Lamellar atrophy & - & - & - & - & - & - & - & + & - & - & - & + & - & - & + & + \\
\hline
\end{tabular}




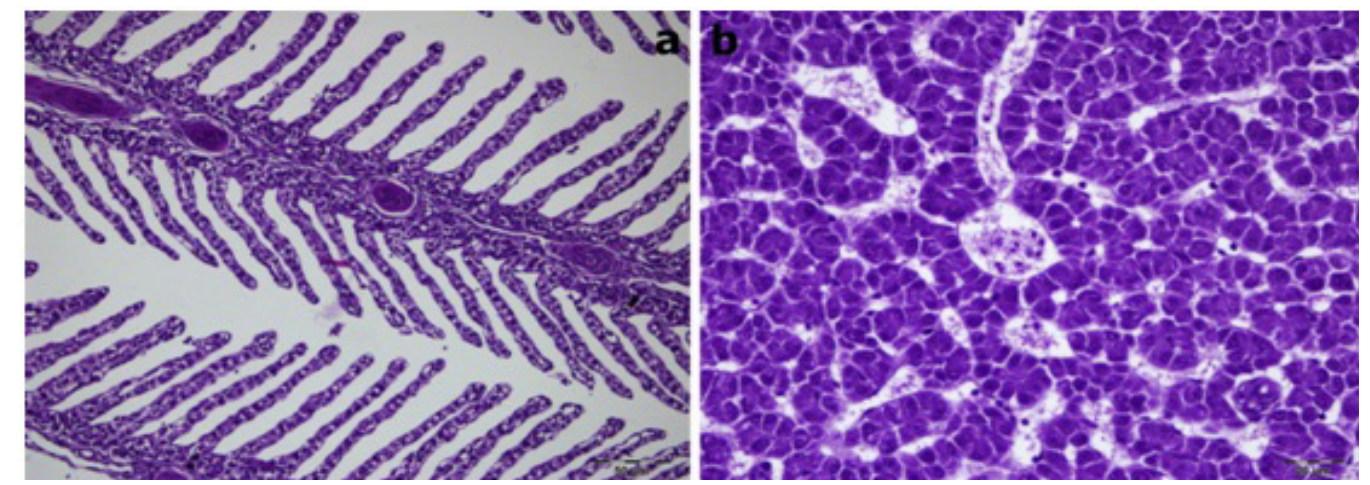

Figure 3 Normal histological appearances of gill (left) and liver (right) sections control group
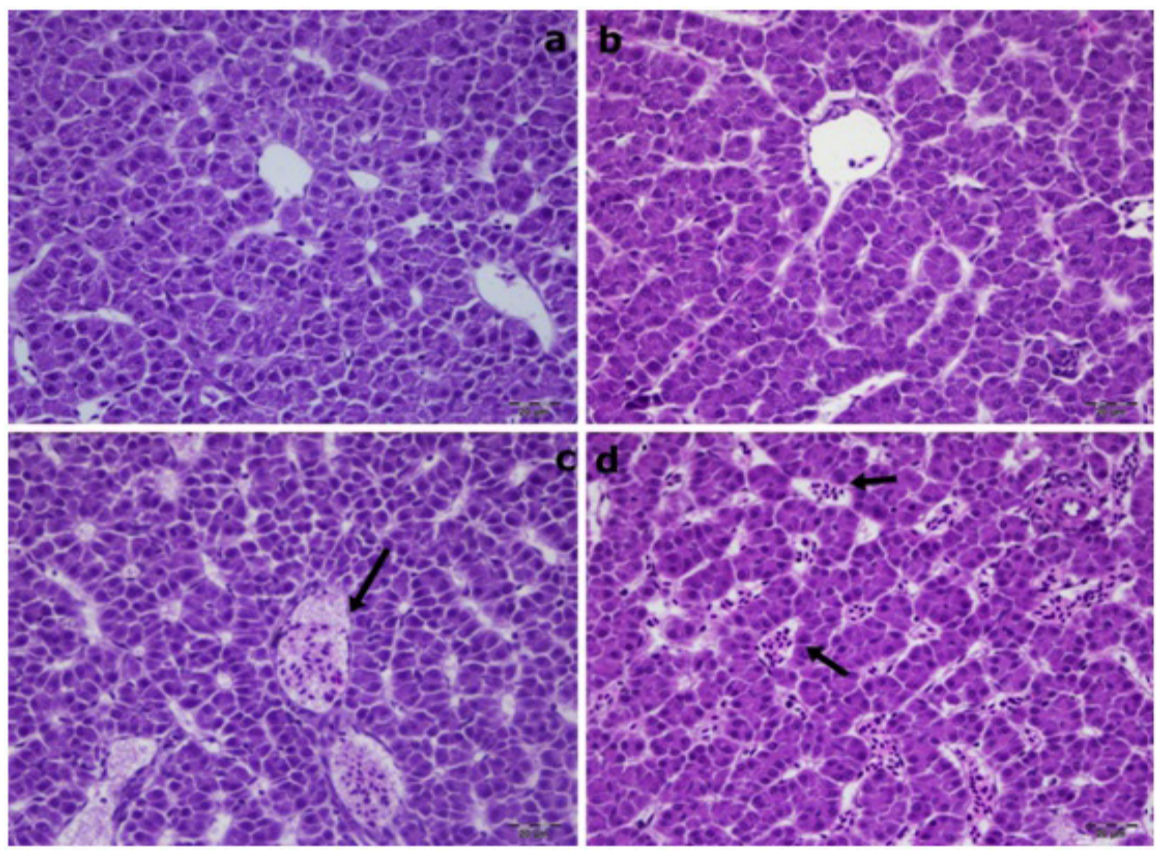

Figure 4 There was no histopathological change in the liver tissues at $2.25 \mu \mathrm{g} L^{-1}$ of chlorpyrifos (a and b). Dilated and hyperaemic central veins (arrow in c) and sinusoids (arrows in d) at 48, 72, and $96 \mathrm{~h}$ of 4.5 and $6.75 \mu \mathrm{g} \mathrm{L} \mathrm{L}^{-1}$ of chlorpyrifos

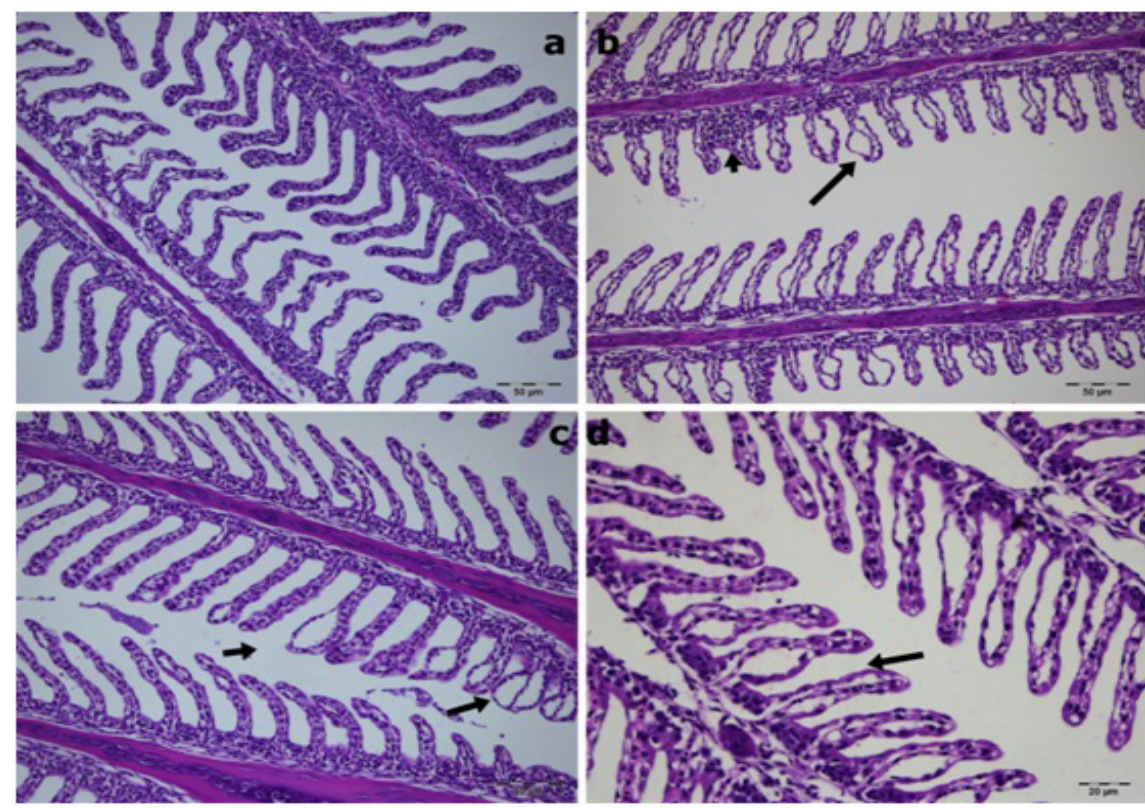

Figure 5 Gill tissue sections from fish exposed to $2.25 \mu \mathrm{g} L^{-1}$ of chlorpyrifos. Curled lamellas (a) at $24 \mathrm{~h}$ and severe oedematous changes (arrows in b-d) at 48, 72, and 96 h, respectively 


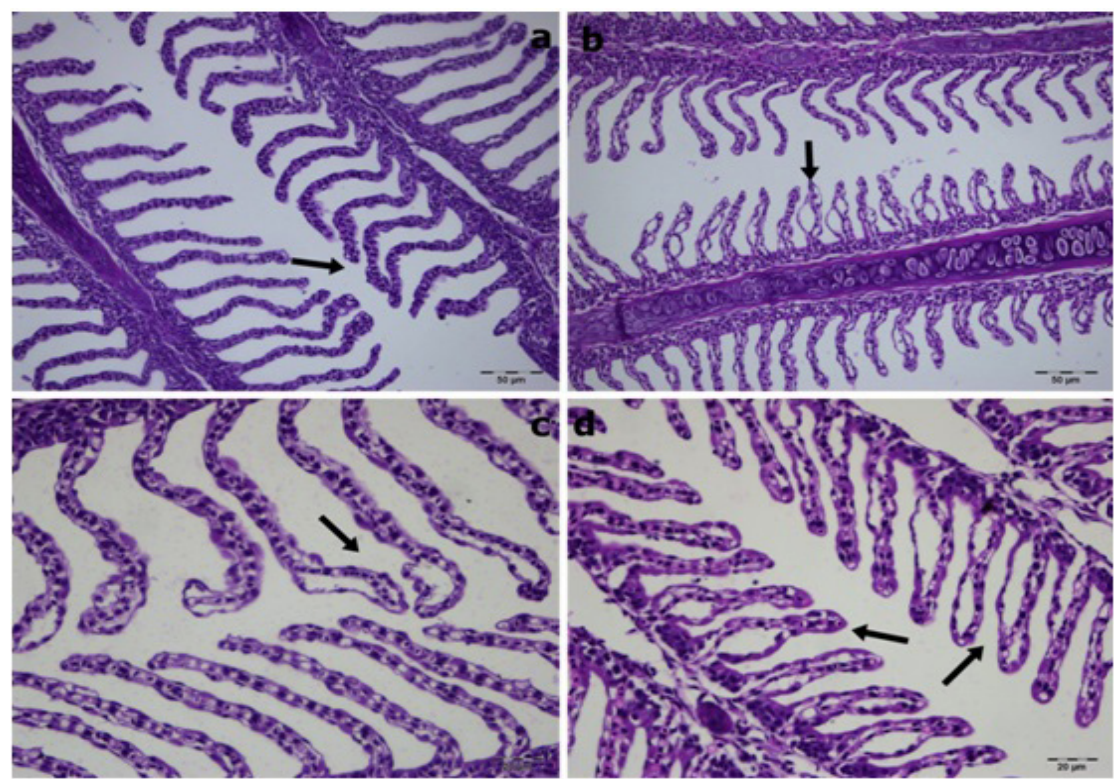

Figure 6 Gill tissue sections from fish exposed to $4.5 \mu \mathrm{g} \mathrm{L} \mathrm{L}^{-1}$ of chlorpyrifos. Curled lamellas and clumpings (arrow in a) at $24 \mathrm{~h}$ severe oedematous changes (arrows in b-d) at 48, 72, and 96 h, respectively

Omar et al. (44) observed hypertrophy, epithelial lifting, desquamation and lamellar fusion in the gill tissues of Aphanius dispar exposed to pesticide temephos which is known as a non-systemic organophosphorus pesticide. Our study has shown results very similar to these.

In conclusion, our results generally suggest that chlorpyrifos inhibits the CA enzyme and causes histopathological damages in gill and liver tissues under in vivo conditions, which proves that fish in both cultured and natural environments are sensitive to this pesticide and that chlorpyrifos contaminations would cause fish deaths. Therefore, stricter control must be applied to the use of this pesticide.

\section{REFERENCES}

1. Narra MR. Tissue-specific recovery of oxidative and antioxidant effects of chlorpyrifos in the freshwater crab, Barytelphusa guerini. Arch Environ Contam Toxicol 2014;67:158-66. doi: 10.1007/s00244-014-0010-1

2. Qin G, Liu T, Guo Y, Zhang X, Ma E, Zhang J. Effects of chlorpyrifos on glutathione $\mathrm{S}$-transferase in migratory locust, Locusta migratoria. Pestic Biochem Physiol 2014;109:1-5. doi: 10.1016/j.pestbp.2013.12.008

3. Fu Y, Li M, Liu C, Qu JP, Zhu WJ, Xing HJ, Xu SW, Li S. Effect of atrazine and chlorpyrifos exposure on cytochrome P450 contents and enzyme activities in common carp gills. Ecotoxicol Environ Saf 2013;94:28-36. doi: 10.1016/j. ecoenv.2013.04.018

4. Ismail M, Khan QM, Ali R, Ali T, Mobeen A. Genotoxicity of chlorpyrifos in freshwater fish Labeo rohita using Alkaline
Single-Cell Gel Electrophoresis (Comet) assay. Drug Chem Toxicol 2014;37:466-71. doi: 10.3109/01480545.2014.887093

5. Khalil F, Kang IJ, Undap S, Tasmin R, Qiu X, Shimasaki Y, Oshima Y. Alterations in social behavior of Japanese medaka (Oryzias latipes) in response to sublethal chlorpyrifos exposure. Chemosphere 2013;92:125-30. doi: 10.1016/j. chemosphere.2013.02.042

6. Mishra A, Devi Y. Histopathological alterations in the brain (optic tectum) of the freshwater teleost Channa punctatus in response to acute and subchronic exposure to the pesticide Chlorpyrifos. Acta Histochem 2014;116:176-81. doi: 10.1016/j.acthis.2013.07.001

7. Salazar-Lugo R, Mata C, Oliveros A, Rojas LM, Lemus M, Villarroel E. Histopathological changes in gill, liver and kidney of neotropical fish Colossoma macropomum exposed to paraquat at different temperatures. Environ Toxicol Pharmacol 2011;31: 490-5. doi: 10.1016/j.etap.2011.02.002

8. Uner N, Oruç EÖ, Sevgiler Y, Sahin N, Durmaz H, Usta D. Effects of diazinon on acetylcholinesterase activity and lipid peroxidation in the brain of Oreochromis niloticus. Environ Toxicol Pharmacol 2006;21:241-5. doi: 10.1016/j. etap.2005.08.007

9. Demirdağ R, Yerlikaya E, Aksakal E, Küfrevioğlu OI, Ekinci D. Influence of pesticides on the $\mathrm{pH}$ regulatory enzyme, carbonic anhydrase, from European Seabass liver and bovine erythrocytes. Environ Toxicol Pharmacol 2012;34:218-22. doi: 10.1016/j.etap.2012.04.007

10. Ma J, Liu Y, Niu D, Li X. Effects of chlorpyrifos on the transcription of CYP3A cDNA, activity of acetylcholinesterase, and oxidative stress response of goldfish (Carassius auratus). Environ Toxicol 2013; Epub Nov 4 doi: 10.1002/tox.21918

11. Kokushi E, Uno S, Pal S, Koyama J. Effects of chlorpyrifos on the metabolome of the freshwater carp, Cyprinus carpio. Environ Toxicol 2013; Epub Aug 30 doi: 10.1002/tox.21903

12. Xing H, Li S, Wang Z, Gao X, Xu S, Wang X. Oxidative stress response and histopathological changes due to atrazine and chlorpyrifos exposure in common carp. Pestic Biochem 

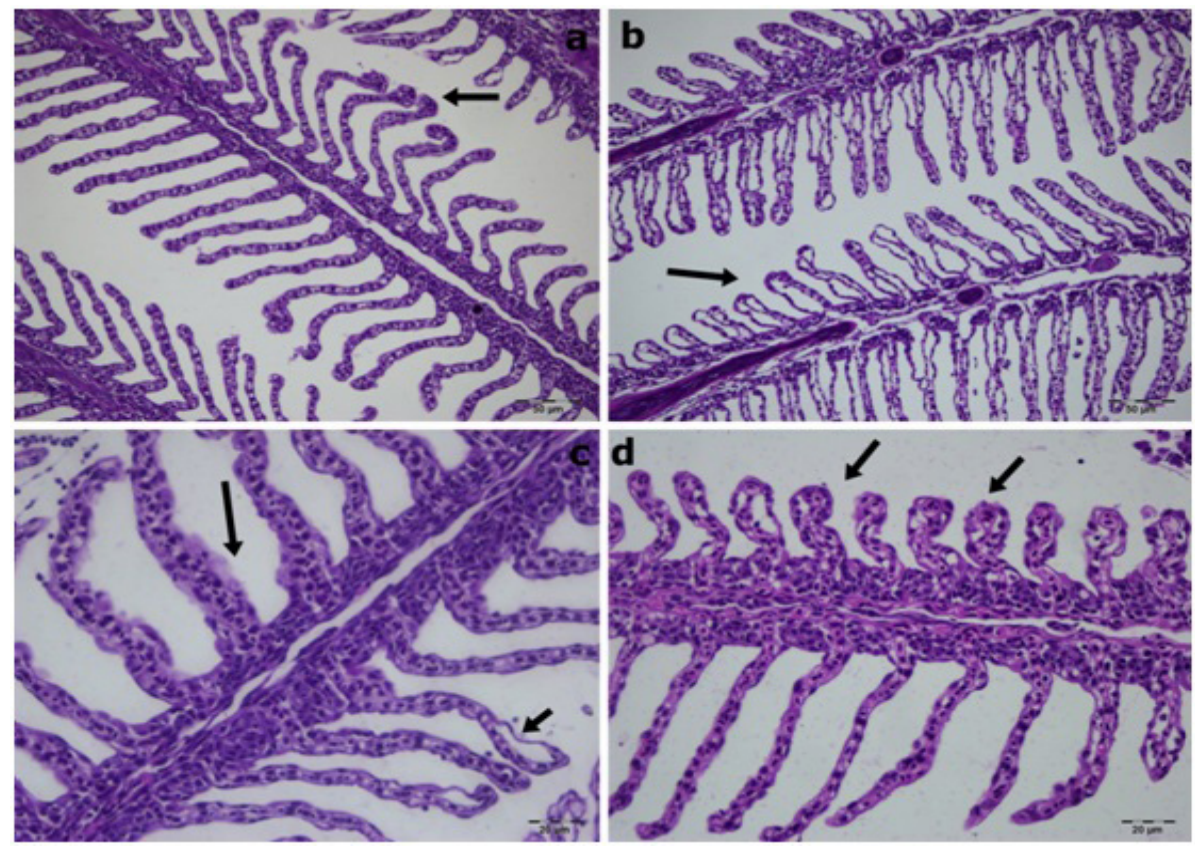

Figure 7 Gill tissue sections from fish exposed to $6.75 \mu \mathrm{g} \mathrm{L} \mathrm{L}^{-1}$ of chlorpyrifos. Curled lamellas and clumpings (arrow in a) at $24 \mathrm{~h}$. Oedematous lamellas (arrow in b) at $48 \mathrm{~h}$, hyperplastic (long arrow in c) at $72 \mathrm{~h}$, and capillary dilatation (arrows in d) in shortened lamellae at $96 \mathrm{~h}$

Physiol 2012;103:74-80. doi: $10.1016 / \mathrm{j}$ chemosphere.2012.02.049

13. Xing H, Li S, Wang Z, Gao X, Xu S, Wang X. Histopathological changes and antioxidant response in brain and kidney of common carp exposed to atrazine and chlorpyrifos. Chemosphere 2012;88:377-83. doi: 10.1016/j. chemosphere.2012.02.049

14. Kavitha P, Rao JV. Toxic effects of chlorpyrifos on antioxidant enzymes and target enzyme acetylcholinesterase interaction in mosquito fish, Gambusia affinis. Environ Toxicol Pharmacol 2008;26:192-8. doi: 10.1016/j. etap.2008.03.010

15. Ali D, Nagpure NS, Kumar S, Kumar R, Kushwaha B, Lakra WS. Assessment of genotoxic and mutagenic effects of chlorpyrifos in freshwater fish Channa punctatus (Bloch) using micronucleus assay and alkaline single-cell gel electrophoresis. Food Chem Toxicol 2009;47:650-6. doi: 10.1016/j.fct.2008.12.021

16. Tilton FA, Tilton SC, Bammler TK, Beyer RP, Stapleton PL, Scholz NL, Gallagher EP. Transcriptional impact of organophosphate and metal mixtures on olfaction: copper dominates the chlorpyrifos-induced response in adult zebrafish. Aquat Toxicol 2011;102:205-15. doi: 10.1016/j. aquatox.2011.01.012

17. Ural MS. Chlorpyrifos-induced changes in oxidant/ antioxidant status and haematological parameters of Cyprinus carpio: Ameliorative effect of lycopene. Chemosphere 2013;90:2059-64. doi: 10.1016/j. chemosphere.2012.12.006

18. Ferrari A, Venturino A, Pechén de D’Angelo AM. Muscular and brain cholinesterase sensitivities to azinphos methyl and carbaryl in the juvenile rainbow trout Oncorhynchus mykiss. Comp Biochem Physiol C Toxicol Pharmacol. 2007;146:30813. doi: $10.1016 /$ j.cbpc.2007.04.002

19. Ozaki A, Sakamoto T, Khoo S, Nakamura K, Coimbra MRM, Akutsu T, Okamoto N. Quantitative trait loci (QTLs) associated with resistance/susceptibility to infectious pancreatic necrosis virus (IPNV) in rainbow trout (Oncorhynchus mykiss). Mol Gen Genomics 2001;265:2331. PMID: 11370869

20. Balaydın HT, Soyut H, Ekinci D, Göksu S, Beydemir S, Menzek A, Sahin E. Synthesis and carbonic anhydraseinhibitory properties of novel bromophenols including natural products. J Enzyme Inhib Med Chem 2012;27:43-50. doi: 10.3109/14756366.2011.574131

21. Postel R, Sonnenberg A. Carbonic anhydrase 5 regulates acid-base homeostasis in zebrafish. PLoS One 2012;7(6):e39881. doi: 10.1371/journal.pone.0039881

22. Çoban TA, Beydemir S, Gülçin I, Ekinci D. Morphine inhibits erythrocyte carbonic anhydrase in vitro and in vivo. Biol Pharm Bull 2007;30:2257-61. doi: 10.1248/bpb.30.2257

23. Doğan $\mathrm{S}$. The in vitro effects of some pesticides on carbonic anhydrase activity of Oncorhynchus mykiss and Cyprinus carpio fish. J Hazard Mater 2006;132:171-6. doi:10.1016/j. jhazmat.2005.10.006

24. Kaya ED, Söyüt H, Beydemir S. Carbonic anhydrase activity from the gilthead seabream (Sparus aurata) liver: The toxicological effects of heavy metals. Environ Toxicol Pharmacol 2013;36:514-21. doi: 10.1016/j.etap.2013.05.019

25. Capkin E, Birincioglu S, Altinok I. Histopathological changes in rainbow trout (Oncorhynchus mykiss) after exposure to sublethal composite nitrogen fertilizers. Ecotoxicol Environ Saf 2009;72:1999-2004. doi: 10.1016/j.ecoenv.2009.05.007

26. U.S. Environmental Protection Agency (US EPA). Ambient water quality criteria for chlorpyrifos - 1986. Washington (DC): US EPA; 1986

27. Wilbur KM, Anderson NG. Electrometric and colorimetric determination of carbonic anhydrase. J Biol Chem 1948;176:147-54. PMID: 18886152

28. Ghorashi S, Shajeei H, Vaezi G, Shamoushaki MMN, Babakhani A. Histopathological studies on kidneys and gills of Onchorhynchus mykiss exposed to sublethal concentration 
of ethylenediaminetetraacetic acid (EDTA). Global Veterinaria 2013;10:121-7. doi: 10.5829/idosi. gv.2013.10.2.6667

29. Bernet D, Schmidt H, Meier W, Burkhardt-Holm P, Wahli T. Histopathology in fish: proposal to assess aquatic pollution. J Fish Disease 1999;22:25-34. doi: 10.1046/j.1365-2761.1999.00134.x

30. Beydemir S, Ciftci M, Küfrevioglu ÖI, Büyükokuroglu ME. Effects of gentamicin sulfate on enzyme activities of carbonic anhydrase from human erythrocytes in vitro and from rat erythrocytes in vivo. Biol Pharm Bull 2002;25:966-9. doi: 10.1248/bpb.25.966

31. Ekinci D, Beydemir S. Risk assessment of pesticides and fungicides for acid-base regulation and salt transport in rainbow trout tissues. Pestic Biochem Physiol 2010;97:6670. doi: $10.1016 /$ j.pestbp.2009.12.006

32. Martínez-Tabche L, Estrada B, Galar I. Parathion and salinity effects on gills and mesonephros carbonic anhydrase activity of the fish Oreochromis hornorum. Bull Environ Contam Toxicol 1992;49:929-34. doi: 10.1007/BF00203169

33. Ceyhun SB, Senturk M, Erdogan O, Kufrevioglu OI. In vitro and in vivo effects of some pesticides on carbonic anhydrase enzyme from rainbow trout (Oncorhynchus mykiss) gills. Pestic Biochem Physiol 2010;97:177-81. doi: 10.1016/j. pestbp.2010.01.003

34. Gülçin 1, Beydemir S, Büyükokuroglu ME. In vitro and in vivo effects of dantrolene on carbonic anhydrase enzyme activities. Biol Pharm Bull 2004;27:613-6. doi: 10.1248/ bpb. 27.613

35. Paulino MG, Sakuragui MM, Fernandes MN. Effects of atrazine on the gill cells and ionic balance in a neotropical fish, Prochilodus lineatus. Chemosphere 2012;86:1-7. doi: 10.1016/j.chemosphere.2011.08.033

36. Boran H, Altinok I, Capkin E. Histopathological changes induced by maneb and carbaryl on some tissues of rainbow trout, Oncorhynchus mykiss. Tissue Cell 2010;42:158-64. doi: 10.1016/j.tice.2010.03.004

37. Pal S, Kokushi E, Koyama J, Uno S, Ghosh AR. Histopathological alterations in gill, liver and kidney of common carp exposed to chlorpyrifos. J Environ Sci Health B 2012;47:180-95. doi: 10.1080/03601234.2012.632285

38. Kaya H, Çelik EŞ, Gürkan M, Yılmaz S, Akbulut M. Effects of subchronic exposure to phosalone on oxidative stress and histopathological alterations in common carp (Cyprinus carpio, L., 1758). J Toxicol Environ Health A 2013;76:85364. doi: 10.1080/15287394.2013.823136

39. del Carmen Alvarez M, Fuiman LA. Environmental levels of atrazine and its degradation products impair survival skills and growth of red drum larvae. Aquat Toxicol 2005;74:22941. doi: org/10.1016/j.aquatox.2005.05.014

40. Mallatt J. Fish gill structural changes induced by toxicants and other irritants: a statistical review. Can J Fish Aquat Sci 1985;42:630-48. doi: 10.1139/f85-083

41. Hinton DE, Lauren DJ. Liver structural alterations accompanying chronic toxicity in fishes: potential biomarkers of exposure. In: McCarthy JF, Shugart LR, editors. Biomarkers of environmental contaminations. Boca Raton (FL): Lewis Publisher; 17-57, 1990.

42. Camargo MMP, Martinez CBR. Histopathology of gills, kidney and liver of a Neotropical fish caged in an urban stream. Neotrop Ichthyol 2007;5:327-36. doi. org/10.1590/ S1679-62252007000300013

43. Peebua P, Kruatrachue M, Pokethitiyook P, Singhakaew S. Histopathological alterations of Nile tilapia, Oreochromis niloticus in acute and subchronic alachlor exposure. J Environ Biol 2008;29:325-31. PMID: 18972686

44. Ba-Omar TA, Al-Jardani S, Victor R. Effects of pesticide temephos on the gills of Aphanius dispar (Pisces: Cyprinodontidae). Tissue Cell 2011;43:29-38. doi: 10.1016/j. tice.2010.11.002 


\title{
Sažetak
}

\section{Promjene u razini ugljikove anhidraze i histopatologiji škrga i jetre kalifornijske pastrve nakon} izlaganja klorpirifosu

Klorpirifos je organofosforni pesticid široke primjene u poljoprivredi i ribarstvu. U ovome radu istražili smo njegov učinak na aktivnost enzima ugljikove anhidraze te histopatologiju škrga i jetre u kalifornijske pastrve. Ribe su bile izložene klorpirifosu u koncentracijama $2,25 \mu \mathrm{g} \mathrm{L}^{-1}\left(25 \% 96\right.$-satnog $\left.\mathrm{LC}_{50}\right), 4,5 \mu \mathrm{g} \mathrm{L}^{-1}$ (50 \% 96-satnog $\left.\mathrm{LC}_{50}\right)$ i $6,75 \mu \mathrm{g} \mathrm{L}^{-1}\left(75 \%\right.$ 96-satnog $\left.\mathrm{LC}_{50}\right)$ tijekom 24, 48, 72 i 96 sati. Aktivnost ugljikove anhidraze mjerena je $u$ jetri i škrgama, a histopatološke promjene promatrane su svjetlosnom mikroskopijom. Najčešće promjene u jetri pri većini koncentracija bile su hiperemija i degenerativne promjene. Na tkivu škrga primijećeni su hiperemija i edemi u škržnim listićima, sljepljivanje i degeneracija stanica, hiperplazija te atrofija škržnih listića. Aktivnost ugljikove anhidraze u škrgama smanjila se pri svim koncentracijama nakon 48, 72 i 96 sati izloženosti $(p<0.05)$. Također je uočeno i smanjenje aktivnosti ugljikove anhidraze u jetri ovisno o duljini izloženosti pri svim koncentracijama $(p<0.05)$. Dobiveni rezultati upućuju na to da klorpirifos inhibira aktivnost ugljikove anhidraze i izaziva značajna histopatološka oštećenja u škrgama i jetri.

KLJUČNE RIJEČI: akutna toksičnost; histologija; pesticidi; ribe; svjetlosna mikroskopija

\section{CORRESPONDING AUTHOR:}

\author{
Ahmet Topal, $\mathrm{PhD}$ \\ Department of Basic Sciences \\ Faculty of Fisheries, Ataturk University, \\ Erzurum, Turkey \\ E-mail:drahmettopal@hotmail.com
}

